\title{
Cobitis fusunae, A New Spined Loach Species (Teleostei: Cobitidae) from the Sultan Marsh, (Kayseri, Turkey)
}

\author{
Sultan Sazlığından (Kayseri, Türkiye) Yeni Bir Balık Türü, Cobitis \\ fusunae, (Teleostei: Cobitidae)
}

\author{
Research Article
}

\section{Filiz Özdemir}

Department of Biology, Faculty of Science, Hacettepe University, Ankara, Turkey.

\section{A B S TR AC T}

obitis fusunae is a new species described from the Sultan Marshes, Kayseri Province, Turkey. This species differs from the congener species of Central Anatolian basins by the combination of the following characters (none unique to the species): No black spot on caudal-fin base, having Z4 with dark-black stripe, pigmentation below Z4, merged Z1-Z3 postdorsally, 12-18 small mid dorsal blotches and one lamina circularis in males, two fixed, diagnostic nucleotide substitutions in the mtDNA COI barcode region, and a minimum K2P genetic distance of $5.4 \%$.

\section{Key Words}

Kizilirmak basin, Develi, Cobitis simplicispina, Cobitis turcica, Cobitis evreni.

\section{öz}

obitis fusunae, Türkiye, Kayseri bölgesindeki Sultan Sazlığı'ndan tanımlanan yeni bir türdür. Bu tür Orta

Anadolu havzasılarında dağılım gösteren türlerden; kaudal yüzgeç tabanında siyah nokta bulunmaması, Z4 bandında koyu siyah şeridin bulunması, Z4'ün altında pigmentasyon olması Z1 ve Z3'ün postdorsalde birleşmiş olması, 12-18 küçük orta dorsal leke ve erkeklerde bir lamina circularis bulunması, mtDNA COI barkod bölgesinde iki sabit, diagnostik nükleotit ikamesi ve K2P genetik uzaklığın minimum \%5.4 olması ile farklılık gösterdiği belirlenmiştir

\section{Anahtar Kelimeler}

Kızılırmak Havzası, Develi, Cobitis simplicispina, Cobitis turcica, Cobitis evreni.

Article History: Received: Sep 11, 2018; Revised: Sep 25, 2018; Accepted: Oct 4, 2018; Available Online: Nov 13, 2018.

DOI: $10.15671 /$ HJBC. 2018.265

Correspondence to: F. Özdemir, Department of Biology, Faculty of Science, Hacettepe University, Ankara, Turkey. 


\section{INTRODUCTION}

T he genus Cobitis is one of the most widely distributed Palearctic freshwater fishes with 18 reported species from Turkey, including $C$. battalgili, C. bilseli, C. damlae, C. dorademiri, C. elazigensis, C. evreni, C. fahireae, C. kellei, C. levantina, C. phrygica, C. pontica, C. puncticulata, C. simplicispina, C. sipahilerae, C. splendens, C. strumicae, C. turcica and C. vardarensis [14]. A recent study on the spatial heterogeneity of freshwater fishes in the Mediterranean revealed that some populations of this genus are unrecognized species e.g. population of the Sultan Marshes, an isolated part of the Kizilirmak River basin [5]. Based on the study carried out by Bohlen et al., [6] Cobitis of the Sultan Marshes represents a distinct taxon among $C$. turcica complex group. In addition, according to Çicek et al., [1] the Cobitis populations of the Kızılırmak River basin is $C$. simplicispina and those of the Sultan Marsh represent an undescribed species. The Sultan Marshes has the highest rate of endemism regarding fishes with four endemic species i.e. Aphanius danfordii, Pseudophoxinus elizavetae, Oxynoemacheilus ciceki and Seminemacheilus ahmeti and one unrecognized species i.e. Cobitis sp. $[5,7,8]$. Hence, this study aimed to describe the populations of the genus Cobitis from the Sultan Marsh as a new species based on differences found.

\section{MATERIAL and METHODS}

The fishes were sampled from the Sultan Marshes, Kızılırmak Basin, Kayseri Province by electrofishing device. After anaesthesia using MS222, they were fixed in 5\% buffered formaldehyde and then placed in $72 \%$ ethanol after 48 hours. Morphometric characters were measured using a digital caliper to a precision of $0.1 \mathrm{~mm}$. Meristic counts, measurements of morphological characters and pigmentation pattern's terminology follows Kottelat and Freyhof [9]. Based on Kottelat and Freyhof [9], the last two branched rays of dorsal and anal fins articulating on a single pterygiophore bone were considered as "1/1/2". For morphological comparisons, those species of neighboring basins i.e. Kizilirmak, Ceyhan and Konya-closed basins, including $C$. evreni, C. simplicispina and $C$. turcica that surrounding this isolated region were considered to define diagnosis character of new species. However, the distinguishing characters of this species compared to other members of the genus Cobitis in Turkey are listed as remakes.

$\mathrm{K} 2 \mathrm{P}$ genetic distances between the compared species were calculated with Mega 6 [10] after aligning the sequences by BioEdit (V. 7.1.3) software [11]. In this study, we used the sequences of the previous study [6] which are deposited in the GenBank (Cobitis fusunae n. sp.: KJ552357; C. evreni: KJ552911, KJ553207; C. turcica: KJ552985, KJ553220, KJ552782).

Abbreviations used: $\mathrm{SL}$, standard length; $\mathrm{HL}$, head length; Z1, Z2, Z3, Z4; longitudinal zones of pigmentation along the flank or Gambetta's zones; HUIC, the collection of the Ichthyology Museum, Department of Biology, Hacettepe University; NHVUIC, Nevsehir Hacı Bektas Veli University Ichthyology Collection, Nevşehir.

\section{Results}

\section{Cobitis fusunae, new species}

(Figures. 1-5, Tables 1,2)

Holotype: NHVUIC-17003-1, male, 48.2 mm SL; Turkey: Kayseri prov.: Gurba at Yeşilhisar, Sultan Marsh, 38०12'12.37"N 35०13'55.65"E S. Sungur \& E. Çiçek, 3 December 2017.

Paratypes: NHVUIC-14001-4, 45.3-66.2 mm SL; data same as holotype. - NHVUIC-13001-4, 44.5$74.6 \mathrm{~mm} \mathrm{SL}$; Turkey: Kayseri prov.: Sultan Marsh, 38²3'23.53"N 35²1'54.52" E, E. Çiçek, 1 June 2014.

Additional materials: HUIC-SOY-1a, 13, 44.0-74.3 mm SL; Turkey: Kayseri prov.: Develi, Soysallı, 38²3'18.25"N 35²1'52.01"E, F. Özdemir \& F. Erkakan, 26 August 2013.

Diagnosis: Cobitis fusunae n. sp. is distinguished from $C$. evreni by having pigmentation below Z4 (vs. no pigmentation below Z4), a Z4 with dark-brown stripe (vs. a Z4 consisting blotches), merged Z1-Z3 postdorsally (vs. well-separated longitudinal zones of pigmentation postdorsally), 12-18 small mid dorsal blotches (vs. absent of blotches on mid dorsal), one lamina circularis (vs. two well-developed lamina circularis) in males, and a K2P genetic distance of $8.0 \%$.

Cobitis fusunae n. sp. differs from C. simplicispina by having pigmentation below Z4 (vs. no pigmentation below Z4), a Z4 with dark-brown 
stripe (vs. a Z4 consisting blotches), no strips of head (vs. presence of S1 strip on head), merged Z1-Z3 postdorsally (vs. separated longitudinal zones of pigmentation postdorsally), longer predorsal (52.7-56.9 vs. 51.3-52.4\%SL), and one lamina circularis (vs. two well-developed lamina circularis) in males.

Cobitis fusunae n. sp. is distinguished from $C$. turcica by having merged Z1-Z3 postdorsally (vs. separated longitudinal zones of pigmentation postdorsally), 12-18 small mid dorsal blotches (vs. 22-28 mid dorsal blotches), no black spot on caudal-fin base (vs. a small black spot on the upper part of caudal-fin base), one lamina circularis (vs. two welldeveloped lamina circularis) in males, and a K2P genetic distance of $5.9 \%$.

Description: Morphometric and meristic data are presented in Tables 1-2 and see Figures 1-5 for general appearance. Body elongate and laterally compressed with snout rounded and slightly elongated. Interorbital space narrow. Eye relatively large. Mouth inferior and arched with upper lip lacking fold and lower lip processing wrinkles divided with a median interruption (Figure 6). Short mandibular maxillary and rostral barbels with earlier one larger, and later one nearly reaching to base of maxillary barbel; maxillary barbel reaching beyond the base of mandibular barbel and vertical of nostril posterior edge. Predorsal distance longer than postdorsal distance. Pelvic-fin origin below 2nd or 3rd branched dorsal-fin ray. Margin of dorsal and anal fins almost straight or roundish. Thin and incomplete crest above and below caudal peduncle. Caudal fin truncate. Lateral line imperceptible predorsally, but visible postdorsally. Body covered by small cycloid scales embedded in the skin. Sub-dorsal scales rounded, with reduced focal zone. Branched rays of dorsal fin $7(5)$ or $6(4)^{1 / 2}$, anal fin $5^{1 / 2}$, caudal fin $14(8)$ or $16(1)$ pectoral fin $7(1), 8(6)$ or $9(2)$ and pelvic fin 5 .

Sexual dimorphism: Males pocessing a single lamina circularis at the base of first branched pectoral-fin ray that absent in females. Snout longer (36.3-42.1 vs 31.7-35.9 \% HL) in males.

Coloration: Body yellowish with a dark-brown pigmentation. Mid-dorsal pigmentation consisting
12-17 dark brown blotches often round, squarish, or fused. Longitudinal zones of pigmentation's pattern irregular with small dark-brown spots, sometimes dotes in Z1-Z3. Zone Z1, Z2 and Z3 with many irregular minute to small spots, well-separated up to mid-part of dorsal fin and merged till caudal fin base. Spots on $Z 2$ bigger than those of $Z 1$ and $Z 3$ and $Z 1$ narrower than Z2 and Z3. Z4 with dark-brown pigmentation, without blotches or spots, forming a continuous stripe running from behind the head to caudal fin base. Pigmentation of flanks below Z4 consisting small spots and dots dispersed irregularly. Belly and lower head yellowish-white without colour pattern. No black spots at caudal peduncle base. Dark-brown spots or bars of pigment on dorsal and caudal fins. Fins yellowish/hyaline in live and whitish/hyaline in those of preserved specimens. Head splotchy with brown spots and golden gloss on opercle. Barbels whitish.

Distribution and Habitat: Cobitis fusunae n. sp. is known only from the Sultan Marshes, Kayseri Province. This species inhabits in slow-flowing parts of rivers with sandy and muddy substance. Pseudophoxinus elizavetae, A. danfordii, S. ahmeti and $O$. ciceki co-exists in type locality with C. fusunae n. sp.. Anthropological changes of the Sultan Marshes during last two decades have altered its hydrologic, physical, and biological characteristic due to an irrigation project and despite its conservation plans by laws, the marshes have undergone a quick degradation in recent years. In the marshes, the water levels have decreased significantly, and the marshes encountered several dry periods [12]. Therefore, because of the small dispersal area and low population of all five endemic species of this closed region, this gene pool need a special attention and conservation.

Etymology: The new species is dedicated to Prof. Dr. Füsun Erkakan for her outstanding contributions in systematic studies on Turkish freshwater fishes especially loaches.

Remarks: Cobitis fusunae $\mathrm{n}$. sp. can be distinguished from other species of Cobitis in Turkey easily by different pattern of Iongitudinal zones of pigmentation as following: having merged zones of pigmentation postdorsally with 
no blotches on Z4 (vs. well-separated zones of pigmentation with blotches on Z4 in C. battalgili, C. bilseli, C. dorademiri, C. elazigensis, C. fahireae, C. levantina, C. pontica, C. splendens, C. strumicae, and $C$. varderensis and no zones of pigmentation in C. damlae), no strip on head (vs. possessing strip on head in C. battalgili, C. fahireae, C. kellei, C. levantina, C. pontica, C. puncticulata, C. splendens, C. strumicae, and C. varderensis), no black spots at caudal peduncle base (vs. presence in C. battalgili, C. dorademiri, C. fahireae, C. kellei, C. levantina, C. pontica, C. puncticulata, C. splendens, C. strumicae, and C. varderensis), two fixed, diagnostic nucleotide substitutions in the mtDNA COI barcode region, and a minimum $\mathrm{K} 2 \mathrm{P}$ genetic distance of $5.4 \%$.

Geiger et al. [5] suggested underestimation of species diversity in the members of the genus

Table 1. Morphometric data of Cobitis fusunae n. sp. (holotype: NHVUIC-17003, and paratypes NHVUIC-14001 and NHVUIC-13001 $(n=8)$.

\begin{tabular}{|c|c|c|c|c|c|}
\hline \multirow{3}{*}{ Characters } & \multirow{3}{*}{$\begin{array}{l}\text { Holotype } \\
\text { (male) }\end{array}$} & \multicolumn{4}{|l|}{ Paratypes } \\
\hline & & \multicolumn{2}{|c|}{ female $(n=3)$} & \multicolumn{2}{|l|}{ male $(n=5)$} \\
\hline & & range & mean $\pm S D$ & range & meansSD \\
\hline Standard length (mm) & 48.2 & $45.3-66.2$ & & $44.5-74.6$ & \\
\hline \multicolumn{6}{|l|}{ In percent of Standart Lenght } \\
\hline Body depth at dorsal fin origin & 14.4 & $12.5-17.6$ & $15.3 \pm 2.6$ & $12.4-14.4$ & $13.4 \pm 0.8$ \\
\hline Caudal peduncle depth & 9.8 & $7.8-11.4$ & $9.5 \pm 1.8$ & 8.3-9.9 & $9.3 \pm 0.7$ \\
\hline Predorsal length & 52.7 & $53.9-54.9$ & $54.4 \pm 0.5$ & $52.7-56.9$ & $54.2 \pm 1.6$ \\
\hline Postdorsal length & 35.7 & $35.2-36.2$ & $35.8 \pm 0.6$ & $33.4-37.3$ & $36.1 \pm 1.5$ \\
\hline Prepelvic length & 55.8 & $54.9-57.5$ & $56.2 \pm 1.3$ & $55.8-61.3$ & $58.1 \pm 2.0$ \\
\hline Preanal length & 77.7 & $77.2-81.2$ & $78.9 \pm 2.1$ & $77.8-82.6$ & $80.1 \pm 1.7$ \\
\hline Caudal peduncle length & 14.3 & $10.88-13.3$ & $12.3 \pm 1.3$ & $11.7-14.3$ & $13.3 \pm 0.9$ \\
\hline Dorsal-fin base length & 8.4 & $8.4-10.2$ & $9.1 \pm 1.0$ & $6.7-9.1$ & $8.3 \pm 0.83$ \\
\hline Dorsal-fin depth & 15.3 & $11.7-19.4$ & $16.2 \pm 4.0$ & 14.1-17.4 & $15.3 \pm 1.3$ \\
\hline Anal-fin base length & 7.3 & $5.7-8.0$ & $7.0 \pm 0.7$ & $5.1-8.6$ & $6.7 \pm 1.2$ \\
\hline Anal-fin depth & 12.6 & $10.9-14.4$ & $12.1 \pm 2.0$ & 11.3-16.9 & $12.8 \pm 2.1$ \\
\hline Pectoral fin length & 16.2 & $11.2-18.2$ & $14.5 \pm 3.5$ & $12.5-17.6$ & $14.5 \pm 2.1$ \\
\hline Pelvic fin length & 11.5 & 8.4-12.1 & $10.3 \pm 1.9$ & $9.3-13.1$ & $10.9 \pm 1.3$ \\
\hline Distance between pectoral and pelvic-fin origins & 33.5 & $32.1-36.0$ & $34.4 \pm 1.6$ & $33.5-40.5$ & $36.3 \pm 2.4$ \\
\hline Distance between pelvic and anal-fin origins & 21.3 & $21.2-25.8$ & $22.8 \pm 1.5$ & $19.2-24.5$ & $22.2 \pm 2.0$ \\
\hline Body width at dorsal fin origin & 6.5 & $6.0-8.9$ & $7.3 \pm 1.4$ & $6.5-9.9$ & $7.5-1.3$ \\
\hline Caudal peduncle width & 2.8 & $2.8-4.0$ & $3.5 \pm 0.7$ & $2.6-3.5$ & $3.0 \pm 0.4$ \\
\hline Head length (HL) & 19.6 & $19.7-20.4$ & $20.1 \pm 0.4$ & $16.7-21.0$ & $18.9 \pm 1.8$ \\
\hline \multicolumn{6}{|l|}{ In percent of Head Lenght } \\
\hline Snout length & 39.2 & $31.7-35.9$ & $33.6 \pm 2.1$ & $36.3-42.1$ & $38.9 \pm 2.1$ \\
\hline Horizontal eye diameter & 15.7 & 15.7-19.1 & $17.5 \pm 1.7$ & $14.1-19.2$ & $16.0 \pm 2.0$ \\
\hline Postorbital distance & 50.9 & $43.9-49.4$ & $46.4 \pm 2.7$ & $47.2-55.5$ & $49.4 \pm 3.3$ \\
\hline Head depth at nape & 60.4 & $57.4-69.0$ & $64.0 \pm 6.0$ & $57.0-68.6$ & $62.0 \pm 4.4$ \\
\hline Head depth at eye & 43.6 & $45.6-48.6$ & $47.1 \pm 1.5$ & $43.6-50.1$ & $46.1 \pm 2.8$ \\
\hline Dorsal head length & 75.6 & $75.6-90.7$ & $84.9 \pm 8.1$ & $75.6-86.7$ & $79.4 \pm 3.9$ \\
\hline Head width at nape & 37.6 & $36.6-42.4$ & $38.8 \pm 3.2$ & $33.4-42.0$ & $37.5 \pm 3.1$ \\
\hline Interorbital distance & 13.9 & $14.6-15.9$ & $15.0 \pm 0.8$ & $12.3-15.7$ & $14.1 \pm 1.3$ \\
\hline Internasal distance & 15.1 & $11.9-15.9$ & $14.2 \pm 2.0$ & $12.4-16.2$ & $13.8 \pm 1.5$ \\
\hline Mouth width & 17.5 & $15.6-16.5$ & $16.0 \pm 0.5$ & $13.8-17.5$ & $15.7 \pm 1.4$ \\
\hline Inner rostral barbel length & 8.7 & $7.7-15.9$ & $12.0 \pm 4.1$ & $6.9-12.5$ & $9.3 \pm 2.4$ \\
\hline Outer rostral barbel length & 16.1 & $12.2-16.4$ & $13.9 \pm 2.2$ & $10.7-16.1$ & $13.3 \pm 1.9$ \\
\hline Maxillary barbel length & 17.5 & $16.0-18.6$ & $17.2 \pm 1.3$ & $14.1-19.5$ & $16.7 \pm 1.8$ \\
\hline
\end{tabular}


Cobitis from Turkey and candidate the Cobitis population of the Sultan Marshes as a new species. Therefore, we compared COI gene of our collected specimens from the Sultan Marshes with that of NCBI GenBank (KJ552357) and the results showed both share the same COI [5].

Comparative Materials (All from Turkey): Cobitis evreni: - NHVUIC-14002, 10, 77.3-104.2 mm SL; Söğütlü Stream, Ceyhan basin, 38014'18.71"N 37017'38.23"E; S. Sungur \& E. Çiçek, August 2014.
Cobitis turcica: - NHVUIC-15001, 14, 65.7-92.2 mm SL; Aksaray prov.: Selime, Melendiz River, Konya Closed Basin, 38¹7'53.48"N 34¹5'48.06"E; S. Sungur \& E. Çiçek, June 2015.

Cobitis simplicispina: - HUIC -SA=9b, 68.3-93.2 mm SL; Ankara prov., Güdül Kirmir Stream: Sakarya Basin, 40¹3'12.77"N 32014'38.68"E; F. Erkakan, June 2000- NHVUIC-14003, 4, 69.992.9 mm SL; Nevşehir prov., Kozaklı, Kızılırmak Basin, 39011'27.49"N 3446'40.52"E; S. Sungur \& E. Çiçek, August 2014.

Table 2. Meristic data of Cobitis fusunae n. sp.

\begin{tabular}{|c|c|c|c|c|c|}
\hline \multirow{3}{*}{ Characters } & \multirow{3}{*}{$\begin{array}{l}\text { Holotype } \\
\text { (male) }\end{array}$} & \multicolumn{4}{|c|}{ Paratypes } \\
\hline & & \multicolumn{2}{|c|}{ female $(n=3)$} & \multicolumn{2}{|c|}{ male $(n=5)$} \\
\hline & & range & mode & range & mode \\
\hline Mid-line blotches & 14 & $14-16$ & 15 & $12-17$ & 16 \\
\hline Branched dorsal-fin rays & 7 & $6-7$ & 7 & $6-6$ & 6 \\
\hline Branched anal-fin rays & 5 & $5-5$ & 5 & $5-5$ & 5 \\
\hline Pectoral-fin rays & 9 & $7-8$ & 8 & $8-9$ & 8 \\
\hline Pelvic-fin rays & 5 & $5-5$ & 5 & $5-5$ & 5 \\
\hline Caudal-fin rays & 14 & $14-16$ & 14 & $14-14$ & 14 \\
\hline
\end{tabular}

Figure 1. Cobitis fusunae n. sp., not catalogued, Turkey: Kayseri prov.: Sultan Marshes.

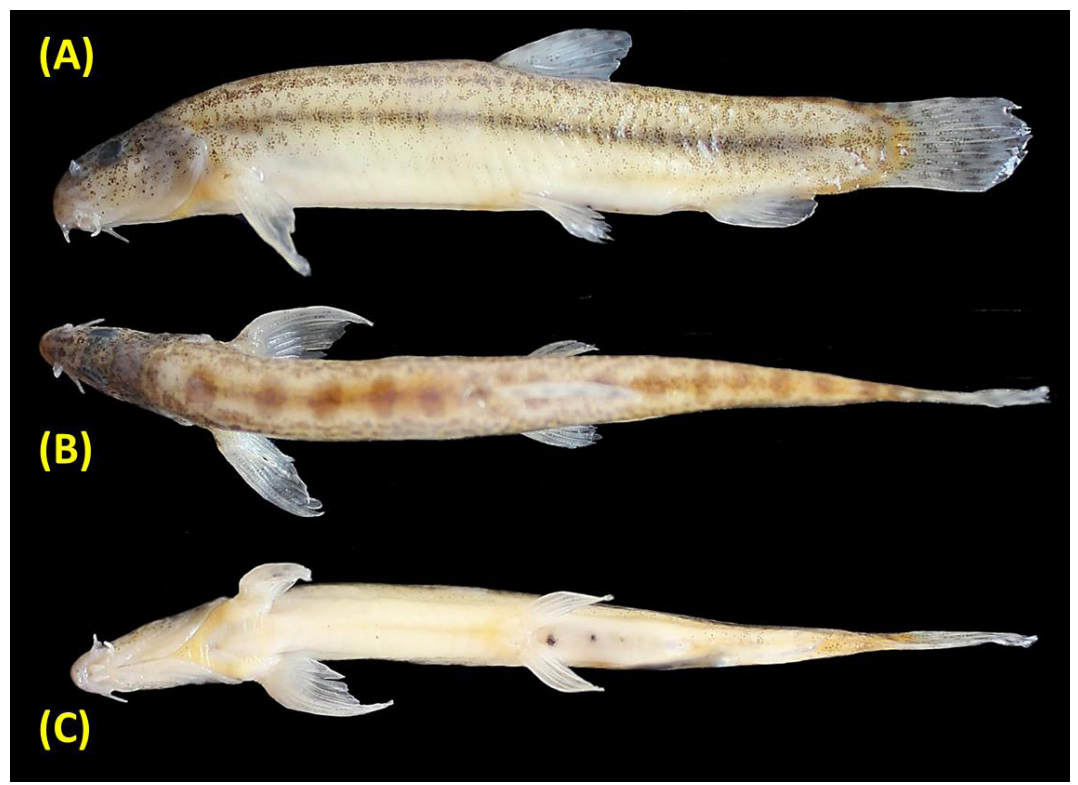

Figure 2. Cobitis fusunae n. sp., NHVUIC-17003, holotype, 48.2 mm SL, Turkey: Kayseri prov.: Sultan Marshes. 


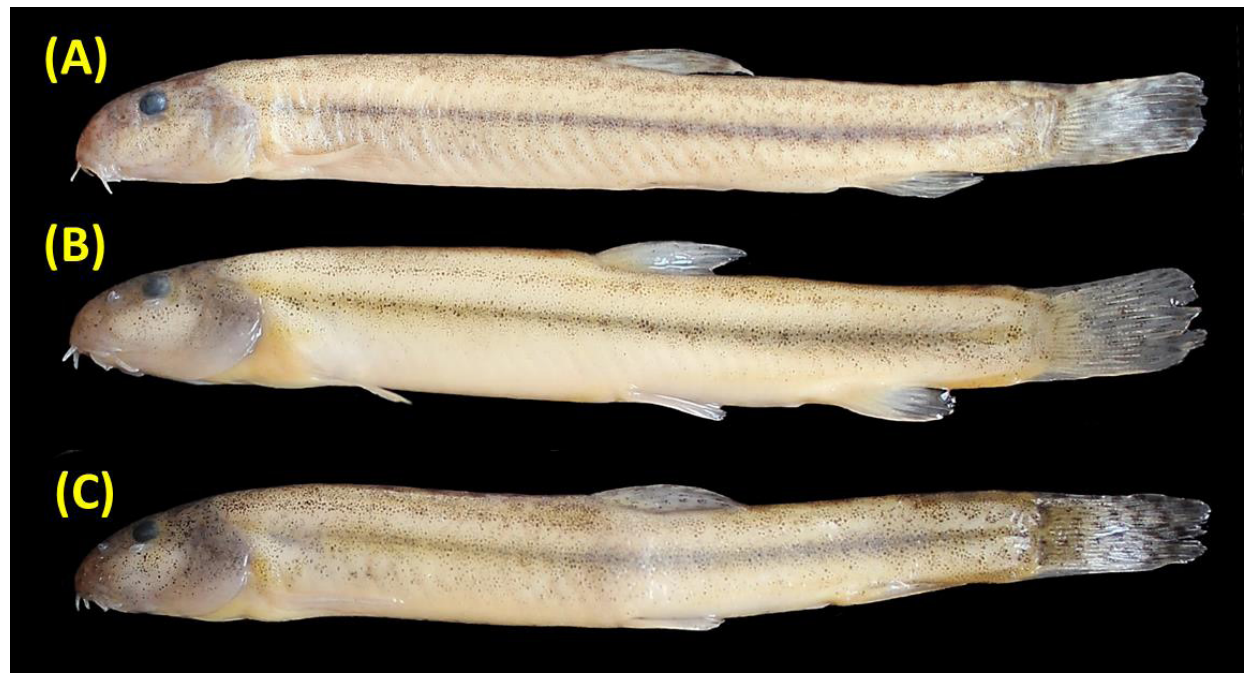

Figure 3. Cobitis fusunae n. sp., paratypes; Turkey: Kayseri Prov.: Sultan Marshes; (A) NHVUIC-14001-4-1, 65.9 mm SL; (B) NHVUIC-14001-4-2, $48.1 \mathrm{~mm} \mathrm{SL;} \mathrm{(C)} \mathrm{NHVUIC-14001-4-3,} 52.1 \mathrm{~mm} \mathrm{SL}$

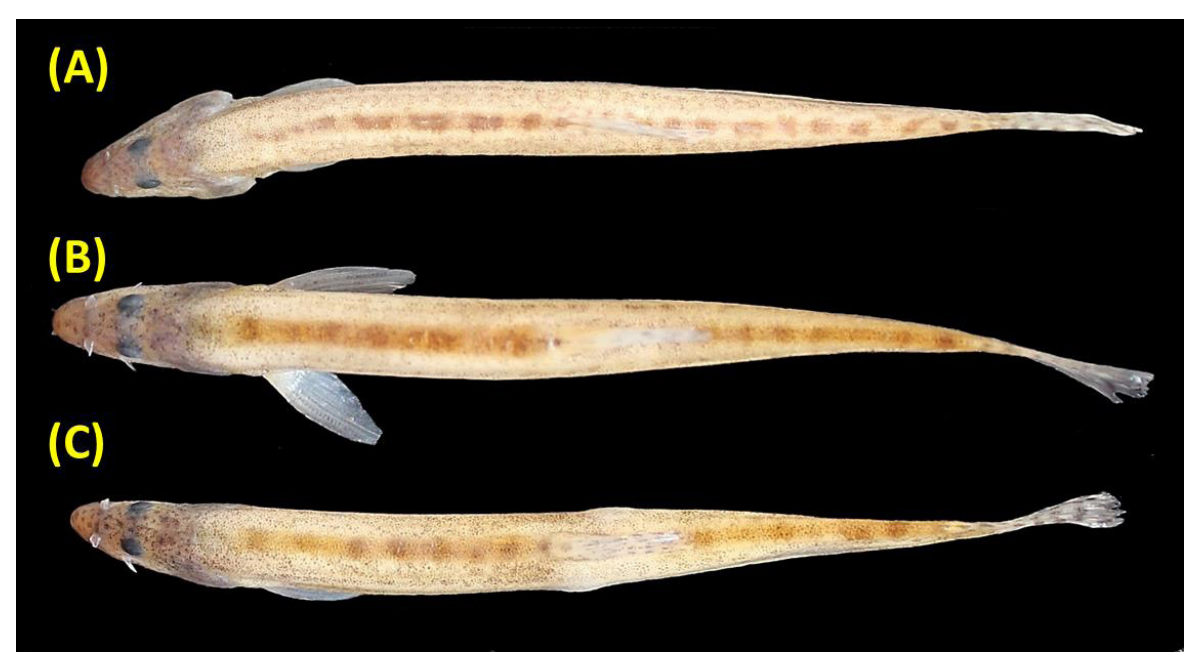

Figure 4. Cobitis fusunae n. sp., paratypes; Turkey: Kayseri Prov.: Sultan Marshes; (A) NHVUIC-14001-4-1, 65.9 mm SL; (B) NHVUIC-14001-4-2, $48.1 \mathrm{~mm} \mathrm{SL;} \mathrm{(C)} \mathrm{NHVUIC-14001-4-3,} 52.1 \mathrm{~mm} \mathrm{SL}$

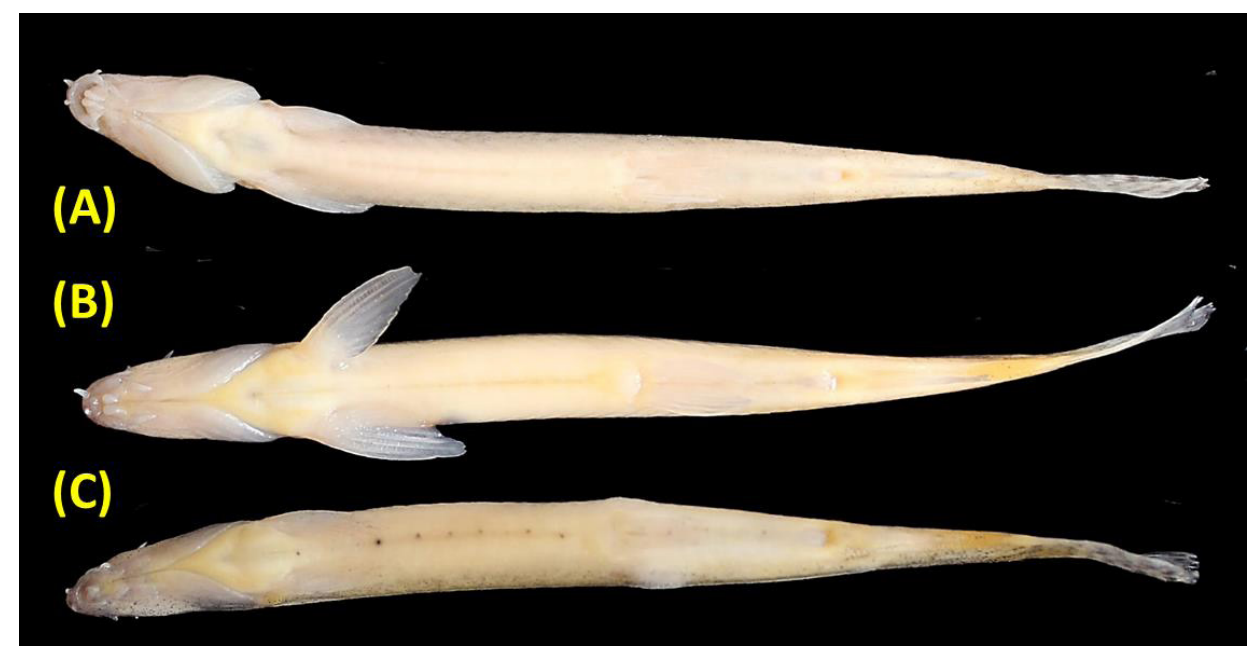

Figure 5. Cobitis fusunae n. sp., paratypes; Turkey: Kayseri Prov.: Sultan Marshes; (A) NHVUIC-14001-4-1, 65.9 mm SL; (B) NHVUIC-14001-4-2, $48.1 \mathrm{~mm} \mathrm{SL;} \mathrm{(C)} \mathrm{NHVUIC-14001-4-3,} 52.1 \mathrm{~mm} \mathrm{SL}$ 


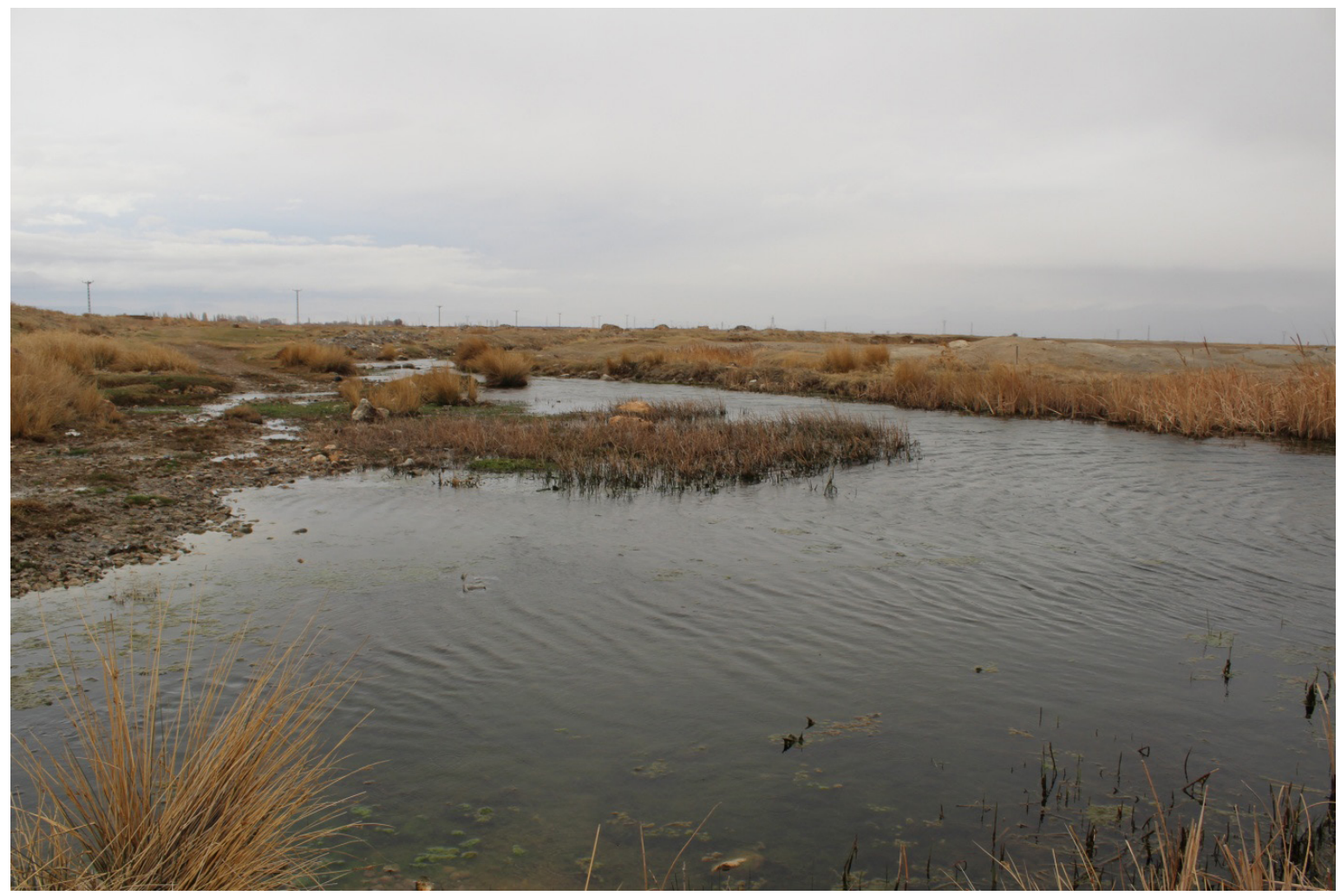

Figure 6. Sultan Marshes, Kayseri province, type locality of Cobitis fusunae n. sp.

\section{Acknowledgements}

Some of the specimens were collected during the projects namely "Determination and Biomonitoring of Aquatic and Terrestrial Biodiversity of Kayseri Province" supported by General Directorate of Nature Protection and National Parks, Ministry of Agriculture and Forestry and "Revision of the species complex Cobitis turcica (Osteichthtes: Cobitidae) endemic to Turkey" supported by Hacettepe University Scientific Research Coordination Unit (project number: 013D05601018). We would like to thank to Harun Dindar, Gülhan Kurtyemez and Saadet Yılmaz for their supports. We are also grateful to Prof. Dr. Erdoğan Çiçek for his valuable scientific support.

\section{References}

1. E. Çiçek, S. Sungur Birecikligil, R. Fricke, Freshwater fishes of Turkey: a revised and updated annotated checklist, Biharean Biologist, 9 (2015) 141-157.

2. A. Jouladeh-Rodbar, S. Eagderi, G. Sayyadzadeh, H.R. Esmaeili, Cobitis keyvani, a junior synonym of Cobitis faridpaki (Teleostei: Cobitidae), Zootaxa, 4244 (2017) 118-126.

3. S. Eagderi, A. Jouladeh, P. Jalili, G. Sayyadzade, H.R. Esmaeili, Taxonomic status of the genus Cobitis Linnaeus, 1758 (Teleostei: 5. Cobitidae) in the southern Caspian Sea basin, Iran with description of a new species, FishTaxa, 2 (2017) 48-61.

4. F. Erkakan, F. Özdemir, S.C. Özeren, Two new species of the genus Cobitis Linnaeus (Teleostei: Cobitidae) from Turkey, FishTaxa, 2 (2017) 82-89
5. M.F. Geiger, F. Herder, M.T. Monaghan, V. Almada, R. Barbieri, M. Bariche, J. Freyhof, Spatial heterogeneity in the Mediterranean biodiversity hotspot affects barcoding accuracy of its freshwater fishes, Molecular Ecology Resources, 14 (2014) 1210-1221.

6. J. Bohlen, A. Perdices, I. Doadrio, P.S. Economidis, Vicariance, colonisation, and fast local speciation in Asia Minor and the Balkans as revealed from the phylogeny of spined loaches (Osteichthyes; Cobitidae), Molecular Phylogenetics and Evolution, 39 (2006) 552-561.

7. S. Sungur, P. Jalili, S. Eagderi, Oxynoemacheilus ciceki, new nemacheilid species (Teleostei, Nemacheilidae) from the Sultan Marsh, Kayseri Province, Turkey, Iranian Journal of Ichthyology, 4 (2017) 375-383.

8. S.Sungur,P.Jalili,S.Eagderi, E. Çiçek,Seminemacheilus ahmeti, a new species of Nemachelid from Sultan Marshes, Turkey, FishTaxa, 3 (2018) 466-473.

9. M. Kottelat, J. Freyhof, Handbook of European freshwater fishes, Delémont, Switzerland, Imprimerie du Démoscrate SA, 646 pp., (2007)

10. K. Tamura, G. Stecher, D. Peterson, A. Filipski, S. Kumar, MEGA6: molecular evolutionary genetics analysis version 6.0, Molecular Biology and Evolution, 30 (2013) 2725-2729.

11. T.A. Hall, BioEdit: a user-friendly biological sequence alignment editor and analysis program for Windows 95/98/NT, Nucleic Acids Symposium Series, 41 (1999) 95-98.

12. F. Dadaser-Celik, H.G. Stefan, P.L. Brezonik, Dynamic hydrologic model of the Örtülüakar Marsh in Turkey, Wetlands, 26 (2006) 1089-1102. 